\title{
ANNUAL SUMMARY
}

\section{Eastern North Pacific Hurricane Season of 1999}

\author{
John L. BeVEn II AND JAMES L. FrankLin \\ Tropical Prediction Center, NWS, NOAA, Miami, Florida
}

(Manuscript received 11 February 2003, in final form 20 October 2003)

ABSTRACT

\begin{abstract}
The 1999 hurricane season in the eastern North Pacific is summarized, and individual tropical storms and hurricanes are described. Producing only nine named storms, the season tied 1996 as the second least active on record. Hurricane Dora was the strongest and longest-lived cyclone of the season. Hurricane Greg, the only cyclone to make landfall during the season, weakened to a tropical storm just before moving ashore in Baja California, Mexico. Fifteen deaths resulted from the tropical cyclones.
\end{abstract}

\section{Introduction}

The eastern North Pacific hurricane basin covers the area north of the equator and east of $140^{\circ} \mathrm{W}$ longitude to Central and North America. Nine tropical storms formed in this basin during the 1999 hurricane season. Of these, six became hurricanes and two became major hurricanes - category 3 or higher (maximum sustained winds of $97 \mathrm{kt}$ or greater) on the Saffir-Simpson Hurricane Scale (Simpson 1974); the 1966-98 averages are 16 tropical storms, 9 hurricanes, and 4 major hurricanes. There were five additional tropical depressions that failed to reach tropical storm intensity. The 1999 season ties the 1996 season (Mayfield and Rappaport 1998) for the second least active since satellite observations began in 1966. Only the 1977 season, with eight tropical storms (Gunther 1978), was less active.

Table 1 lists the tropical storms and hurricanes of 1999, while Fig. 1 shows a map of their tracks. Most of the data used in determining the tracks and intensities (1-min average sustained winds at $10 \mathrm{~m}$ ) are derived from satellites; these include Dvorak (1984) intensity estimates, cloud-drift winds, and ocean surface scatterometer data (e.g., Tsai et al. 2000). Other sources of data include infrequent surface, upper-air, and radar observations. There were no reconnaissance flights into eastern North Pacific tropical cyclones in 1999.

Hurricane Greg, which crossed the southern tip of Baja California, Mexico, as a tropical storm on 7 September, was the only storm to make landfall in 1999. Hurricanes Dora and Eugene crossed $140^{\circ} \mathrm{W}$ into the

Corresponding author address: Dr. John L. Beven II, National Hurricane Center, 11691 SW 17th Street, Miami, FL 33165-2149. E-mail: John.L.Beven@noaa.gov central Pacific basin, with Dora later crossing the international date line into the western North Pacific basin.

One can speculate on the reasons for the inactive season. One possibility is the active 1999 Atlantic season (Lawrence et al. 2001), which featured 16 tropical cyclones (TCs). Climatologically, most eastern North Pacific cyclones can be traced to disturbances (tropical waves) that cross Central America from the Caribbean (Simpson et al. 1969; Avila and Guiney 2000). An increase in the number of Atlantic storms could potentially decrease the vigor of waves crossing into the Pacific. Atlantic Hurricanes Cindy, Dennis, Floyd, Gert, and Jose all formed from tropical waves and then moved out of the Tropics. While tropical waves spawn more than one TC occasionally, the remnant wave vorticity after genesis often appears greatly reduced. A pattern of above-normal activity in the Atlantic coupled with below-normal activity in the eastern Pacific was also noted in 1995, 1996, and 1998. Conversely, the active 1997 season in the eastern Pacific was accompanied by a below-normal number of Atlantic systems. This inverse relationship is intriguing, but does not occur every year, as noted by Lander and Guard (1998).

All 1999 eastern Pacific tropical cyclones (including the nondeveloping tropical depressions) could be associated with Atlantic tropical waves that crossed Central America. However, the background monsoonlike environment may have played a role in the development of several cyclones. In some cases, the wave developed into a tropical cyclone upon entering the favorable background environment. In other cases, the wave may have assisted the development of a preex- 
TABLE 1. Eastern Pacific tropical storms and hurricanes of 1999.

\begin{tabular}{|c|c|c|c|c|c|}
\hline Name & Class* & Dates** & $\begin{array}{c}\text { Max } 1-\min \\
\text { wind speed }(\mathrm{kt})\end{array}$ & $\begin{array}{l}\text { Min sea level } \\
\text { pressure }(\mathrm{mb})\end{array}$ & Deaths \\
\hline Adrian & $\mathrm{H}$ & 18-22 Jun & 85 & 973 & 6 \\
\hline Beatriz & $\mathrm{H}$ & 9-17 Jul & 105 & 955 & \\
\hline Calvin & $\mathrm{T}$ & 25-27 Jul & 35 & 1005 & \\
\hline Dora & $\mathrm{H}$ & 6-23 Aug & 120 & 943 & \\
\hline Eugene & $\mathrm{H}$ & 6-15 Aug & 95 & 965 & \\
\hline Fernanda & $\mathrm{T}$ & 17-22 Aug & 55 & 994 & \\
\hline Greg & $\mathrm{H}$ & 5-9 Sep & 65 & 986 & 9 \\
\hline Hilary & $\mathrm{H}$ & 17-21 Sep & 65 & 987 & \\
\hline Irwin & $\mathrm{T}$ & 8-11 Oct & 50 & 997 & \\
\hline
\end{tabular}

* T: tropical storm, max sustained winds 34-63 kt. H: hurricane, max sustained winds 64 kt or higher.

** Dates based on UTC and include tropical depression stage.

isting monsoon disturbance. Unfortunately, the available data often do not allow for a distinction between the two possibilities.

Figure 2 shows an example of a tropical wave crossing Central America that eventually became Hurricane Greg. In this particular case, a monsoonlike environment with some disturbed weather was in place before the arrival of the wave. However, tropical cyclogenesis did not occur until the wave arrived. Figure 2 suggests that the tropical cyclogenesis showed better spatial and temporal continuity with the preexisting disturbed weather, which in turn suggests that the wave acted as a trigger for the development of the preexisting monsoon disturbance.

Another possible explanation for the reduced activity is that the sea surface temperature (SST) pattern combined with the location of the intertropical convergence zone (ITCZ) to create a smaller than normal area favorable for tropical cyclone formation. Colder than normal SSTs along the equator associated with La Niña, combined with the normal cold SSTs generally north of $20^{\circ} \mathrm{N}$, may have limited the area of warm water necessary for tropical cyclone development and maintenance. This was most notable during August west of $120^{\circ} \mathrm{W}$, where only a $10^{\circ}-12^{\circ}$-wide east-west band of SSTs warmer than $26^{\circ} \mathrm{C}$ existed (not shown).

Figure 3 shows monthly mean $850-\mathrm{mb}$ winds for June, July, August, and September 1999. Note the month-to-month variation in the location and intensity of the ITCZ. During June, the mean position extended from Panama west-northwestward to a few hundred miles southwest of Baja California with mean circulation centers near the western end and just south of southeastern Mexico. Both circulation centers are anomalous (not shown). The western center, while appearing favorable for TC development, is located near cold SSTs. This superposition may have helped suppress activity, as any nascent $\mathrm{TC}$ in this area would likely have encountered cold water before genesis could occur.

Five tropical cyclones formed in July, which is near normal. However, only 2 of these became storms and only $1 \mathrm{a}$ hurricane, numbers that are half of the normal of 4 and 2, respectively. While the mean ITCZ appears weak in July (Fig. 3b), monthly low-level wind anomalies (not shown) suggest it was close to normal strength. Also, 200-850-mb wind shear data (not shown) indicate no obvious inhibiting factors. Thus, the reason for the inactive July remains a mystery.

During August, a well-defined mean ITCZ circulation was centered southwest of Baja California (Fig. $3 \mathrm{c}$ ); it also strongly appeared in monthly wind anomalies (not shown). Hurricane Eugene and Tropical Storm Fernanda formed in the vicinity of this feature, while Hurricane Dora became a major hurricane in that area.

During September, the ITCZ shifted northward to near the coast of Mexico east of $105^{\circ} \mathrm{W}$ (Fig. 3d), creating a strong cyclonic anomaly along $18^{\circ}-20^{\circ} \mathrm{N}$ from $115^{\circ} \mathrm{W}$ eastward into Mexico (not shown). This shift resulted in disturbances passing over or near the mountainous areas of southern Mexico, likely limiting cyclogenesis. Hurricanes Greg and Hilary formed on the southeast side of the mean cyclone centered southwest of Baja California.

\section{Tropical storm and hurricane summaries}

\section{a. Hurricane Adrian: 18-22 June}

A persistent area of disturbed weather located south of the Gulf of Tehuantepec developed a low-level circulation and convective banding on 16 June. This occurred when a tropical wave, which had moved off the west coast of Africa 11 days earlier, moved into the preexisting disturbed area. Further development followed, producing a tropical depression about $225 \mathrm{n} \mathrm{mi}$ southeast of Acapulco, Mexico, near 0600 UTC 18 June (Fig. 1). The depression became Tropical Storm Adrian later that day. A deep-layer ridge over Mexico helped steer the cyclone west-northwestward on a track parallel to the coast of Mexico through 20 June. Adrian became a hurricane on 20 June and maintained an estimated peak intensity of $85 \mathrm{kt}$ from 1800 UTC 20 June to 0000 UTC 21 June. An eye was briefly seen in satellite imagery during this time (not shown). 


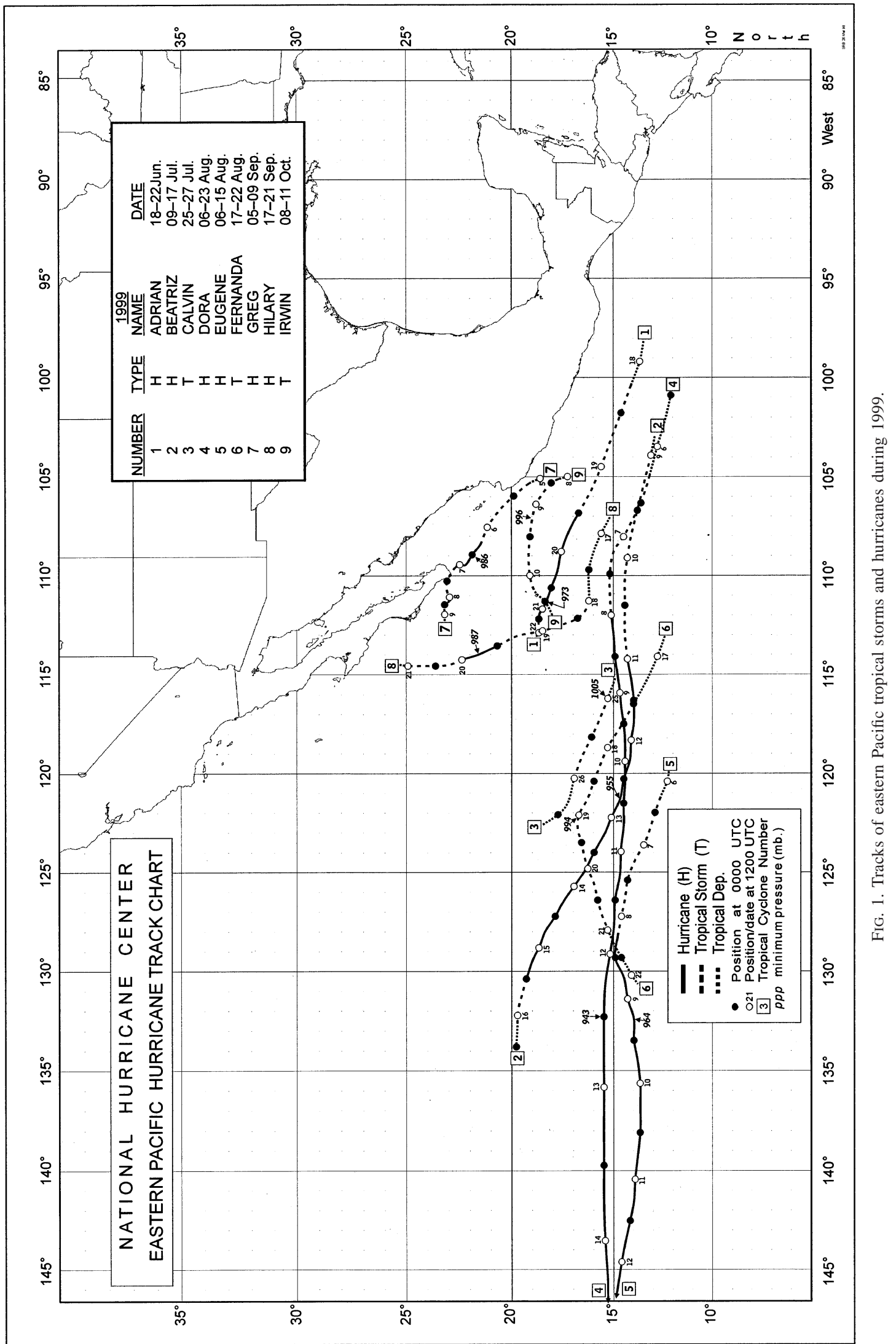




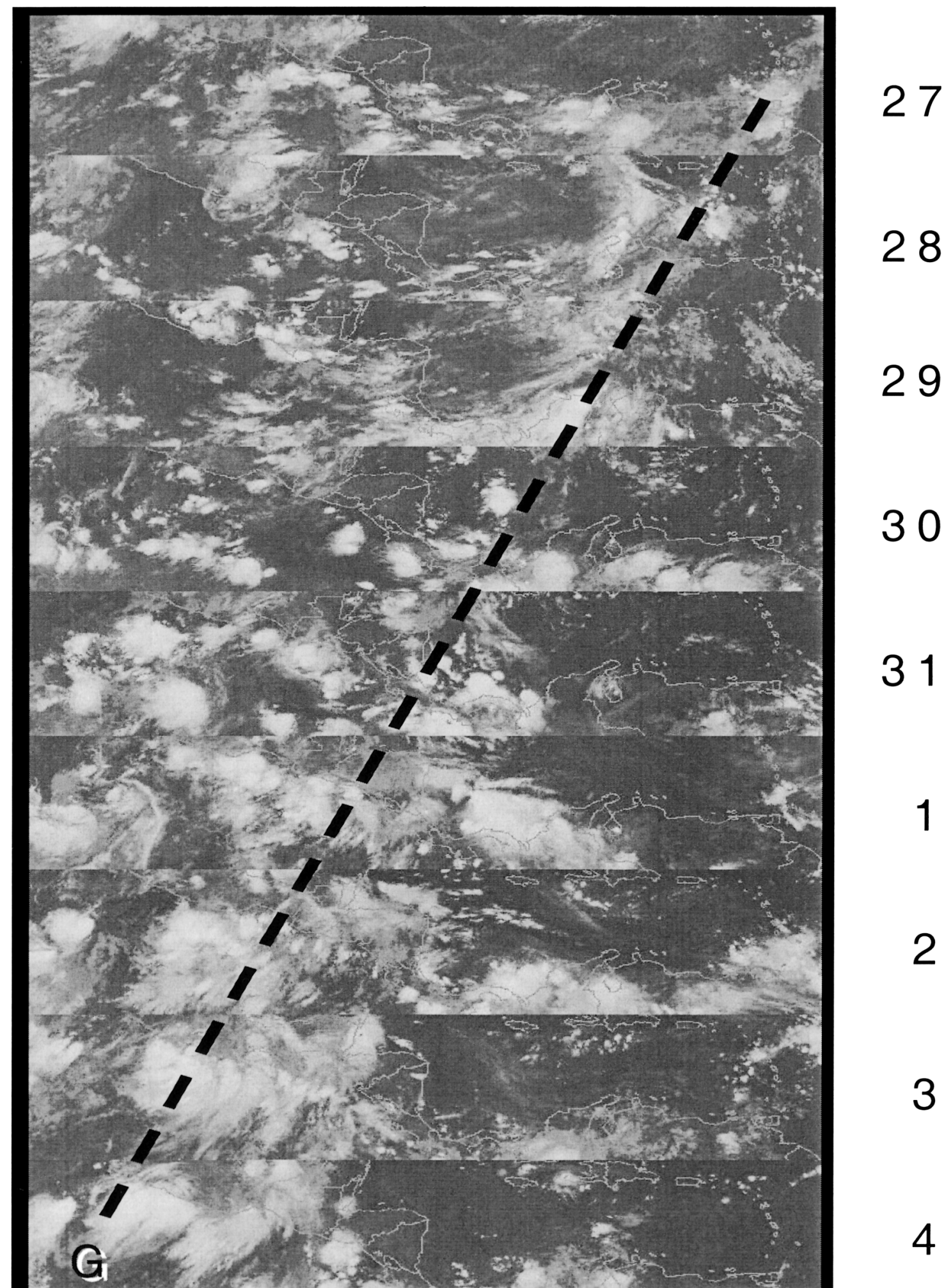

FIG. 2. Sequence of daily Geostationary Operational Environmental Satellite-8 (GOES 8) infrared satellite images at 1200 UTC from 27 Aug to 4 Sep 1999. Dates are indicated on the right-hand side of the figure. Dashed line marks the tropical wave that eventually triggered Hurricane Greg $(\mathrm{G})$. 


\section{June $1999850 \mathrm{mb}$ Winds}

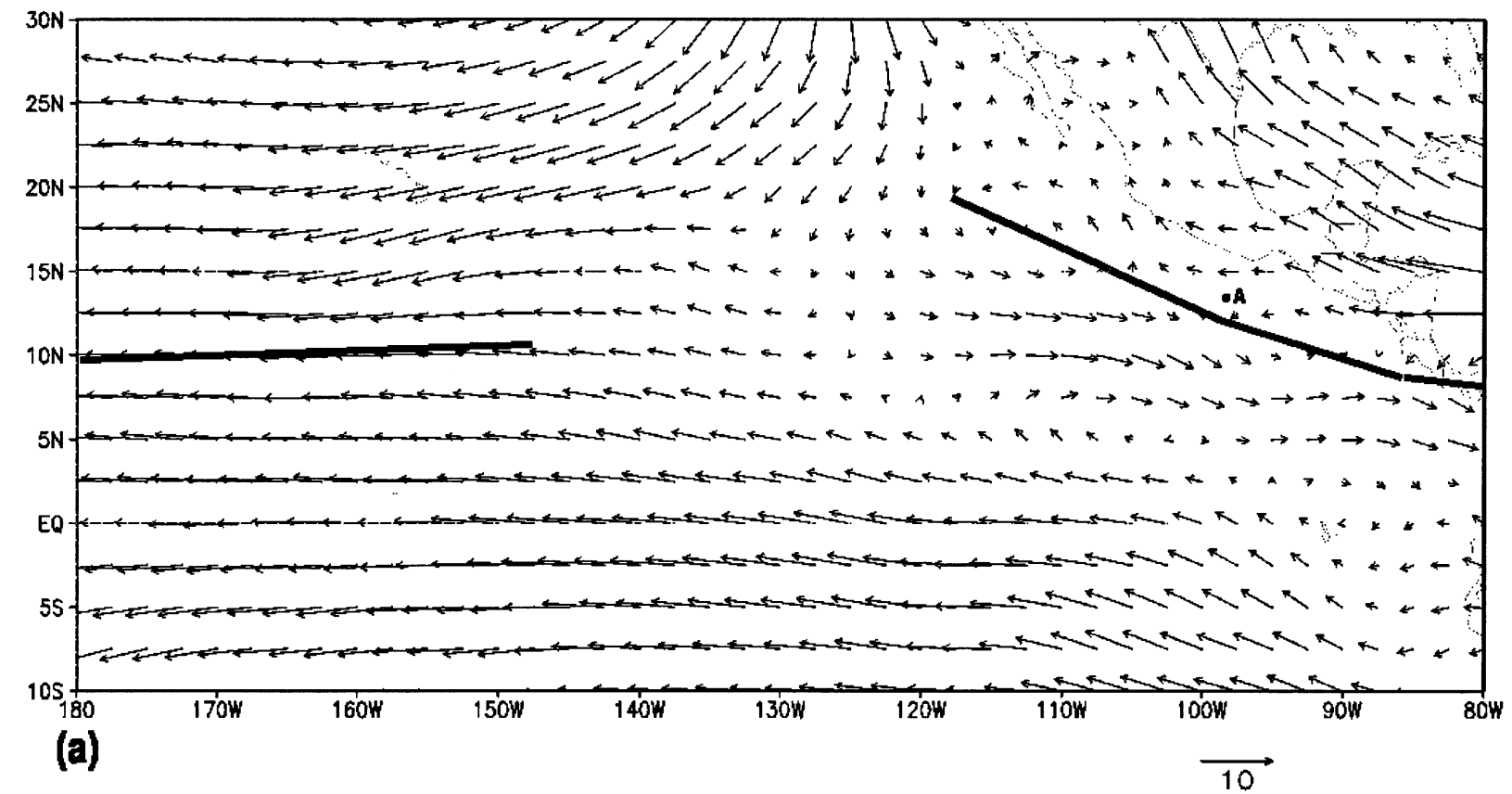

\section{July $1999850 \mathrm{mb}$ Winds}

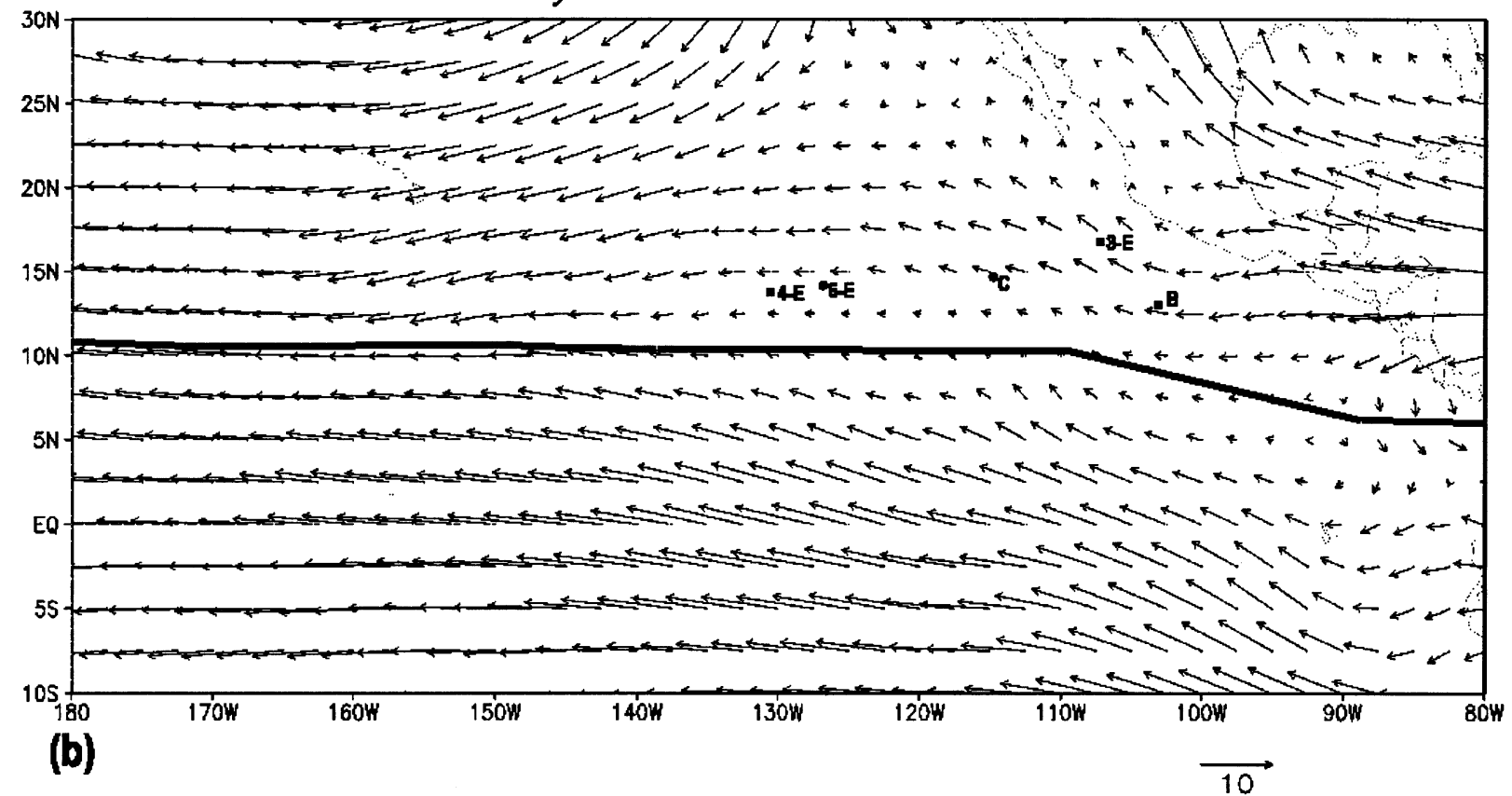

FIG. 3. The 850-mb mean monthly winds for (a) Jun, (b) Jul, (c) Aug, and (d) Sep 1999. Arrow length is proportional to the wind speed $\left(\mathrm{m} \mathrm{s}^{-1}\right)$. Labeled dots show the genesis locations of tropical cyclones. Thick black line is the mean position of the ITCZ inferred from winds. Wind data courtesy of the National Oceanic and Atmospheric Administration Climate Prediction Center.

As the cyclone passed near Socorro Island, Mexico, later on 21 June, southeasterly vertical wind shear and cooler SSTs caused Adrian to weaken to a tropical storm. Adrian turned toward the west and weakened to a de- pression on 22 June. Adrian dissipated later that day, about $300 \mathrm{n}$ mi southwest of Cabo San Lucas, Mexico.

Limited observations in Adrian include a report of 34$\mathrm{kt}$ winds and a 998.6-mb pressure on 19 June from the 
Aug $1999850 \mathrm{mb}$ Winds

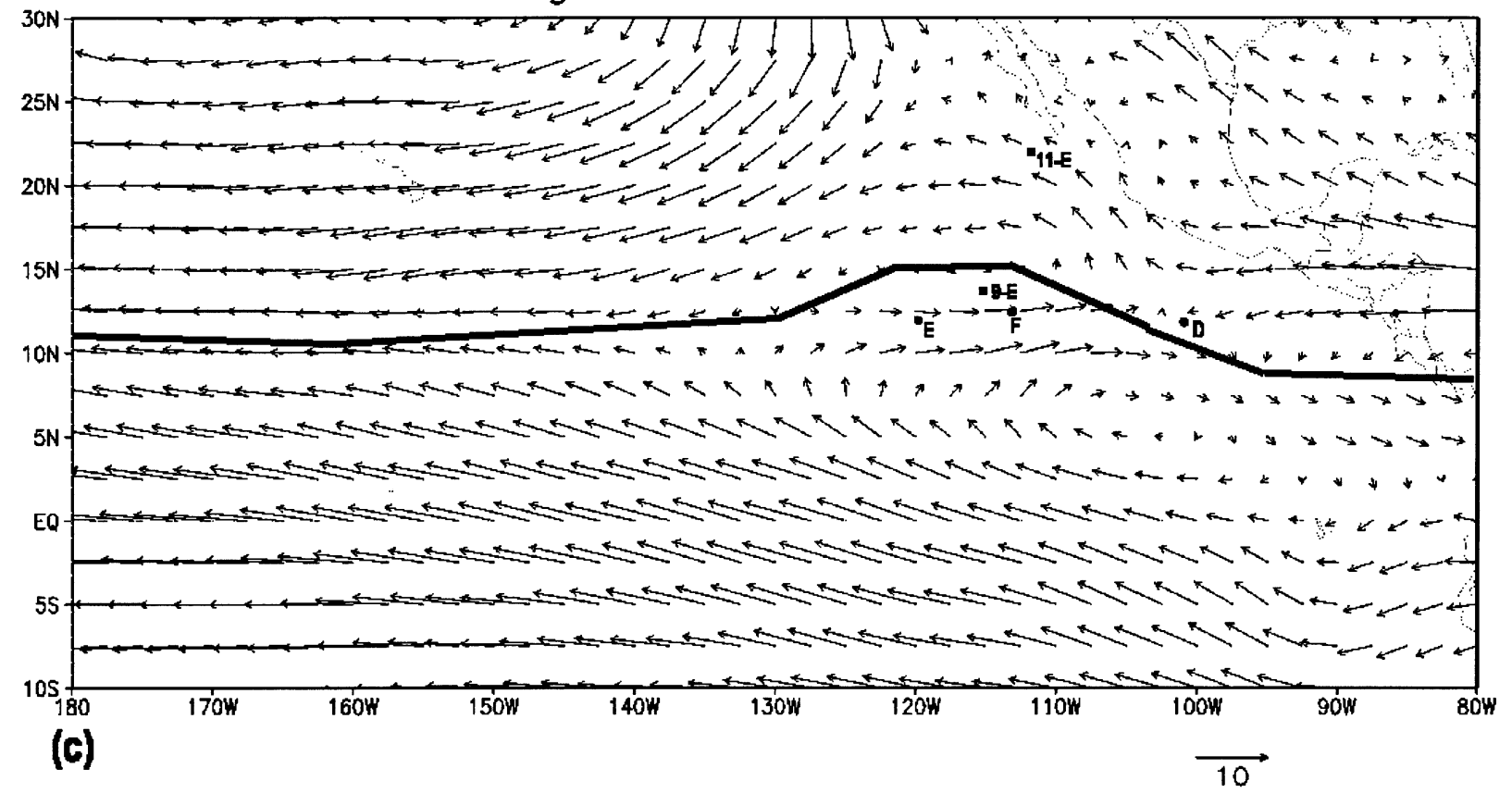

Sep $1999850 \mathrm{mb}$ Winds

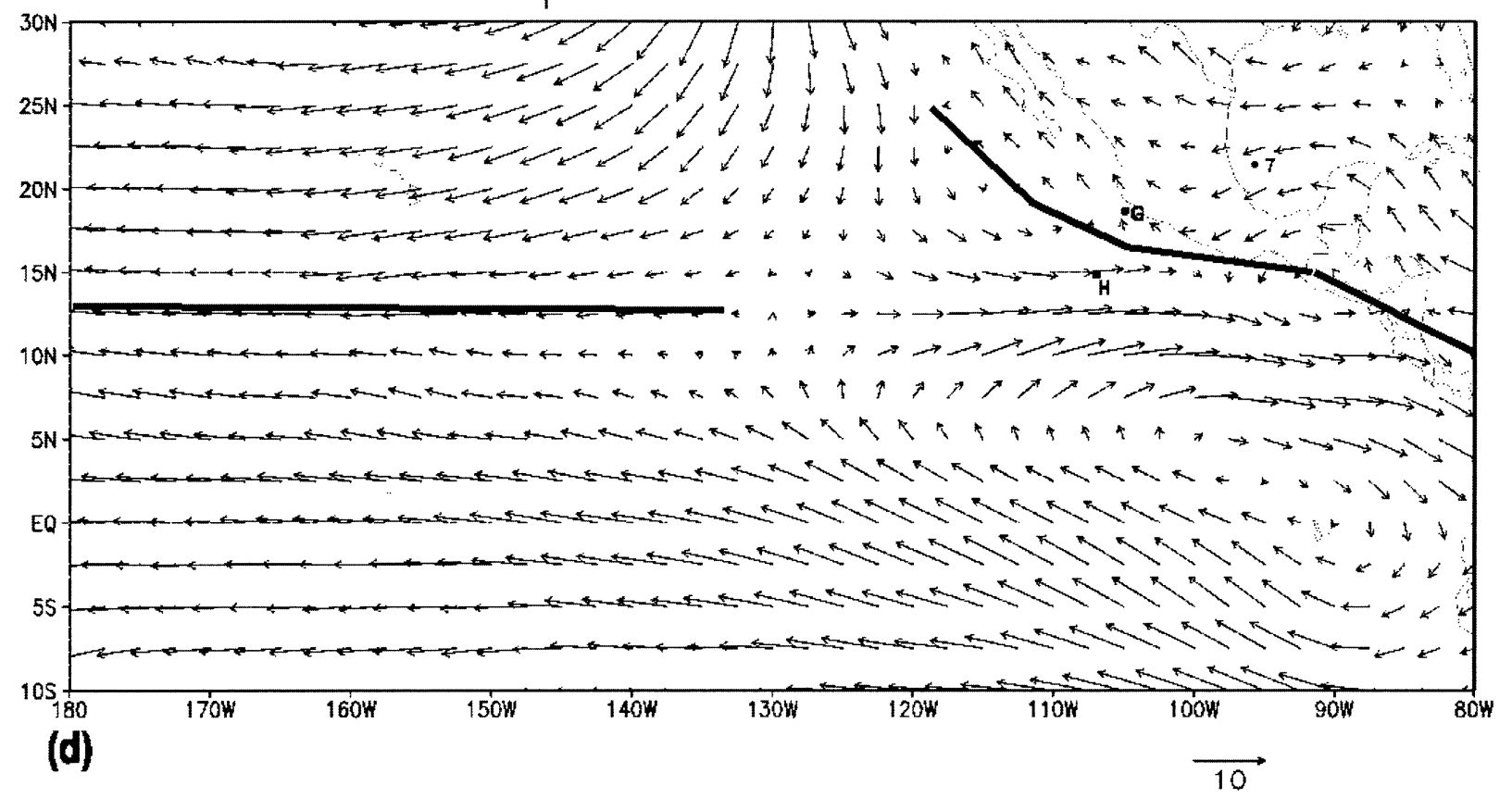

FIG. 3. (Continued)

ship L'atalante. Socorro Island reported 40-kt winds and a 993-mb pressure at 1200 UTC 21 June.

Although Adrian did not make landfall, outer rainbands spread over western Mexico causing two deaths from flash floods. Four other deaths were attributed to high surf.

\section{b. Hurricane Beatriz: 9-17 July}

Beatriz formed from a tropical wave that entered the eastern tropical Atlantic on 26 June. The wave moved over Central America and extreme eastern Mexico on 4-5 July. Disturbed weather consolidated in the vicinity 


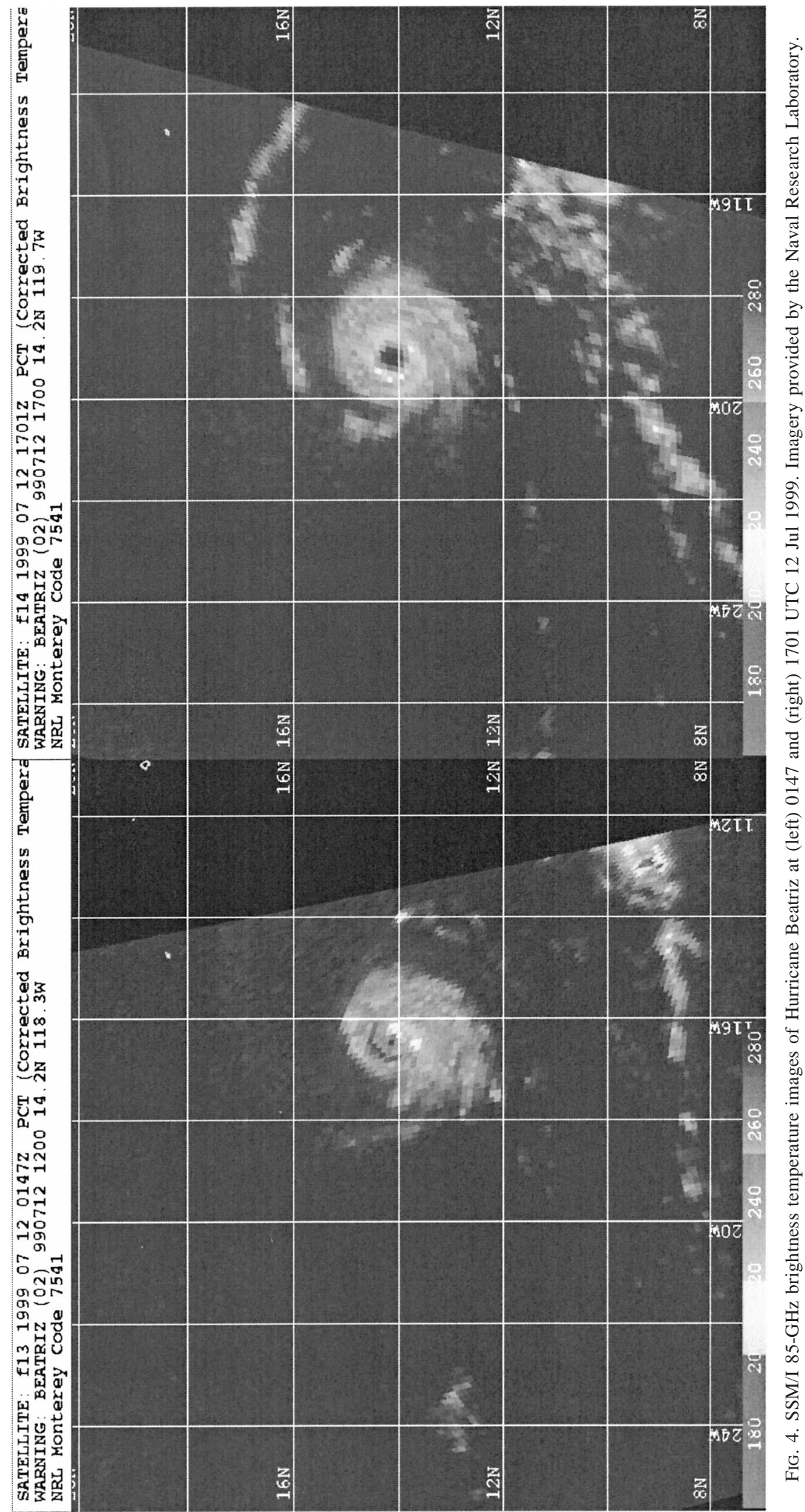


of the wave in the Gulf of Tehuantepec on 6 July, and a cyclonic circulation was evident the next day. Further development was slow, and it was 0600 UTC 9 July before a tropical depression formed about $300 \mathrm{n} \mathrm{mi}$ south of Lazaro Cardenas, Mexico (Fig. 1). The depression moved west-northwestward and became a tropical storm later that day. Beatriz became a hurricane on 11 July while a midtropospheric ridge to its north helped steer the cyclone westward. Intensification stopped temporaily on 12 July; Special Sensor Microwave Imager (SSM/I) data (Fig. 4) suggest this was most likely due to an eyewall replacement cycle. Once this cycle was complete, a well-defined $20 \mathrm{n}$ mi diameter eye formed, and the hurricane reached an estimated peak intensity of $105 \mathrm{kt}$ on 13 July.

A weakness in the subtropical ridge north of Beatriz allowed a west-northwestward motion over gradually cooler waters on 13 July. This resulted in a gradual weakening that lasted through 15 July. More rapid weakening on 16 July reduced Beatriz to a tropical storm and then to a depression. The cyclone turned westward and dissipated the next day, about $1100 \mathrm{n}$ mi east of the Hawaiian Islands.

The only significant surface observation was from the ship Belo Oriente, which reported 35-kt winds about $190 \mathrm{n}$ mi north-northeast of the center at 1200 UTC 13 July.

\section{c. Tropical Storm Calvin: 25-27 July}

A tropical wave that emerged from the west coast of Africa on 9 July crossed Central America into the Pacific Ocean on 20 July. The wave moved into a convectively active ITCZ, with a midlevel circulation developing on 23 July. Additional development produced a tropical depression about $560 \mathrm{n}$ mi southwest of Cabo San Lucas by 0600 UTC 25 July (Fig. 1). Although the low-level center was displaced northwest of the primary convection, the depression became a tropical storm $6 \mathrm{~h}$ later while it moved west-northwestward. West-northwesterly vertical wind shear prevented further intensification and caused Calvin to weaken to a depression on 26 July. Calvin turned to the northwest, and this track continued until the cyclone dissipated about $750 \mathrm{n}$ mi west-southwest of Cabo San Lucas on 27 July.

\section{d. Hurricane Dora: 6-23 August}

A tropical wave that crossed the West Africa coast on 23 July emerged into the eastern Pacific basin on 34 August. The system became better organized the next day and developed into a depression about $290 \mathrm{n} \mathrm{mi}$ south of Acapulco near 0000 UTC 6 August (Fig. 1). The cyclone moved west-northwestward through $8 \mathrm{Au}-$ gust; subsequently, a mid- to upper-level ridge building to the north of the cyclone contributed a westward motion (a motion that would continue until the cyclone entered the central Pacific basin on 14 August). Even though northeasterly vertical shear provided a less than ideal environment, the cyclone became Tropical Storm Dora on 7 August. Decreasing shear on the next day allowed Dora to become a hurricane. Intensification continued, with Dora reaching an estimated peak intensity of $120 \mathrm{kt}$ near 0000 UTC 12 August (Fig. 5). After weakening briefly, perhaps in association with a concentric eyewall cycle inferred from SSM/I and infrared satellite imagery (not shown), Dora regained 120-kt winds near 1800 UTC that day. Although slow weakening followed the second peak, Dora still had estimated 100 -kt winds when it crossed $140^{\circ} \mathrm{W}$ longitude into the central Pacific basin.

Analyses from the Central Pacific Hurricane Center and the Joint Typhoon Warning Center show that Dora then continued westward across the central Pacific, passing south of Hawaii and crossing the international date line into the western North Pacific as a tropical storm on 20 August. Dora weakened to a depression on 22 August and dissipated the next day about $550 \mathrm{n} \mathrm{mi}$ north-northwest of Wake Island, a full month after its seedling disturbance crossed the African coast.

Dora was the longest-lived and strongest eastern Pacific tropical cyclone of 1999 and was a major hurricane for 4 days. It was also the first eastern Pacific tropical cyclone to spend time in all three Pacific tropical cyclone basins since Hurricane John did so in 1994 (Pasch and Mayfield 1996).

\section{e. Hurricane Eugene: 6-15 August}

Eugene had its origin in a tropical wave that crossed Central America on 28-29 July and moved westward for several days with little sign of organization. Convection associated with the wave became more consolidated on 5 August, and the system became a tropical depression near 0600 UTC the next day about $850 \mathrm{n} \mathrm{mi}$ southwest of Cabo San Lucas (Fig. 1). The cyclone moved west-northwestward and became a tropical storm later that day. A strengthening ridge to its north helped turn Eugene generally westward on 8-9 August, allowing the cyclone to stay over warm water and intensify. Eugene became a hurricane on 8 August and developed a $10 \mathrm{n} \mathrm{mi} \mathrm{diameter} \mathrm{eye.} \mathrm{It} \mathrm{reached} \mathrm{an} \mathrm{estimated} \mathrm{peak}$ intensity of $95 \mathrm{kt}$ the next day. This occurred near $133^{\circ} \mathrm{W}$, which is significantly farther west than the climatological location of peak intensity for eastern Pacific tropical cyclones. Slow weakening ensued, and Eugene crossed into the central Pacific near 0900 UTC $11 \mathrm{Au}-$ gust with 75-kt winds.

Eugene continued generally westward across the central Pacific and slowly weakened, becoming a tropical storm on 13 August. A west-southwestward motion on 14 August brought Eugene to a region of increased vertical wind shear, and the cyclone weakened to a tropical depression. Eugene dissipated the next day about $500 \mathrm{n} \mathrm{mi}$ southeast of Johnston Island. 


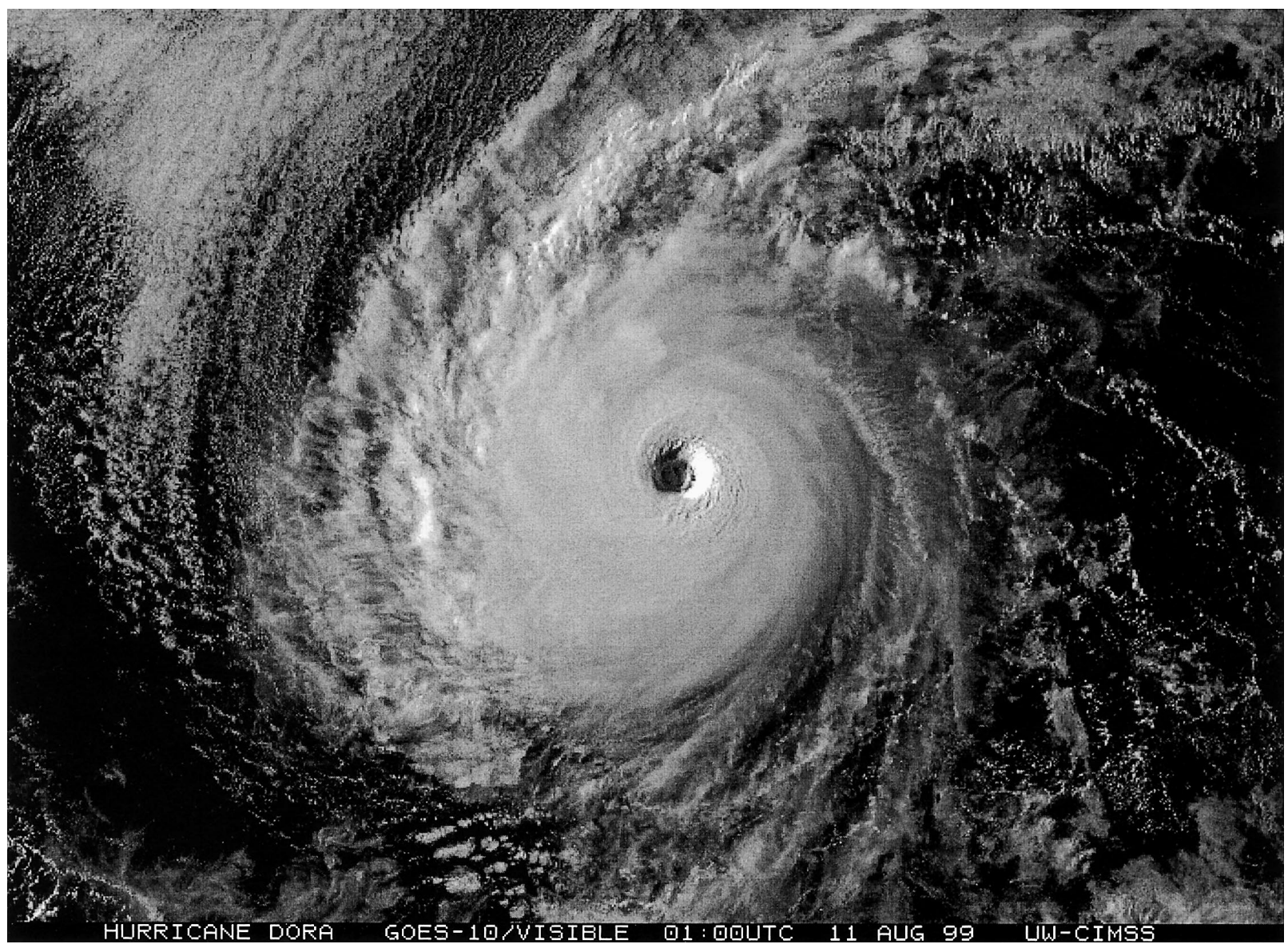

FIG. 5. GOES-10 visible image of Hurricane Dora at 0100 UTC 11 Aug 1999. Imagery provided by the Cooperative Institute for Meteorological Satellite Studies, University of Wisconsin-Madison.

\section{f. Tropical Storm Fernanda: 17-22 August}

The tropical wave that spawned Fernanda emerged from the African coast on 1 August. Convection associated with the wave increased when it moved into the eastern North Pacific basin on 10 August. Slow and gradual development occurred while the wave continued westward over the next several days. A low-level circulation within the system became better defined on 16 August, and scatterometer winds from the European Remote Sensing Satellite-2 (ERS-2) indicated that a tropical depression formed near 0600 UTC 17 August, about $400 \mathrm{n}$ mi south-southwest of Socorro Island (Fig. 1). The depression moved west-northwestward becoming a tropical storm the next day. Fernanda reached an estimated peak intensity of $55 \mathrm{kt}$ on 19 August. Fernanda turned west-southwestward, a track that kept the cyclone over warm SSTs but took the system into an environment of increasing easterly vertical wind shear. Fernanda weakened to a depression on 21 August and dissipated the next day about $1300 \mathrm{n} \mathrm{mi} \mathrm{west-southwest} \mathrm{of}$ Cabo San Lucas.

\section{g. Hurricane Greg: 5-9 September}

Hurricane Greg developed, in part, from the same tropical wave that triggered Tropical Storm Emily in the Atlantic east of the Lesser Antilles on 24 August (Lawrence et al. 2001). After spawning Emily, the southern portion of the wave continued westward and crossed Central America during 31 August and 1 September (Fig. 2). Thunderstorm activity became concentrated while cloud-banding featured developed on 3-4 September, and the system became a tropical depression near Manzanillo, Mexico, at 1200 UTC 5 September (Fig. 1). It is of interest that the combination of the favorable monsoonal environment and tropical wave was also responsible for the genesis of Tropical Depression 7 in the western Gulf of Mexico on 5 September. Thus this wave was involved in the genesis of three tropical cyclones.

A report of 42-kt winds and a pressure of $1006.5 \mathrm{mb}$ at 1800 UTC 5 September from the ship Hume Highway indicated the depression had become Tropical Storm Greg by that time. While Greg moved on a general northwestward track very close to the coast of Mexico, 
TABLE 2. A homogeneous comparison of official and CLIPER track forecast errors ( $\mathrm{mi}$ ).

\begin{tabular}{|c|c|c|c|c|c|c|}
\hline & \multicolumn{6}{|c|}{ Forecast period (h) } \\
\hline & 0 & 12 & 24 & 36 & 48 & 72 \\
\hline 1999 Avg official error & 8.6 & 32.2 & 60.1 & 83.2 & 103.7 & 135.2 \\
\hline 1999 Avg CLIPER error & 8.6 & 35.1 & 70.2 & 106.5 & 143.0 & 215.9 \\
\hline No. of cases & 128 & 128 & 114 & 102 & 90 & 69 \\
\hline 1989-98 Avg official error & 12.0 & 37.8 & 70.5 & 103.8 & 135.4 & 194.5 \\
\hline 1989-98 Avg CLIPER error & 12.0 & 40.1 & 76.8 & 117.2 & 157.0 & 228.7 \\
\hline No. of cases & 2580 & 2574 & 2308 & 2035 & 1786 & 1367 \\
\hline
\end{tabular}

a large area of very deep convection formed near the center. Radar from Los Cabos, Mexico, suggested the formation of a ragged eye during the morning of 6 September. Figure 6 shows a visible satellite image of Greg near this time. Greg became a hurricane at 1800 UTC that day while it approached the southern portion of
Baja California. Northeasterly vertical wind shear prevented further intensification, and no significant change in strength occurred for the next $24 \mathrm{~h}$. Thereafter, Greg weakened to a tropical storm as it made landfall near Cabo San Lucas around 2100 UTC 7 September. Greg turned west-northwestward, then westward, and moved

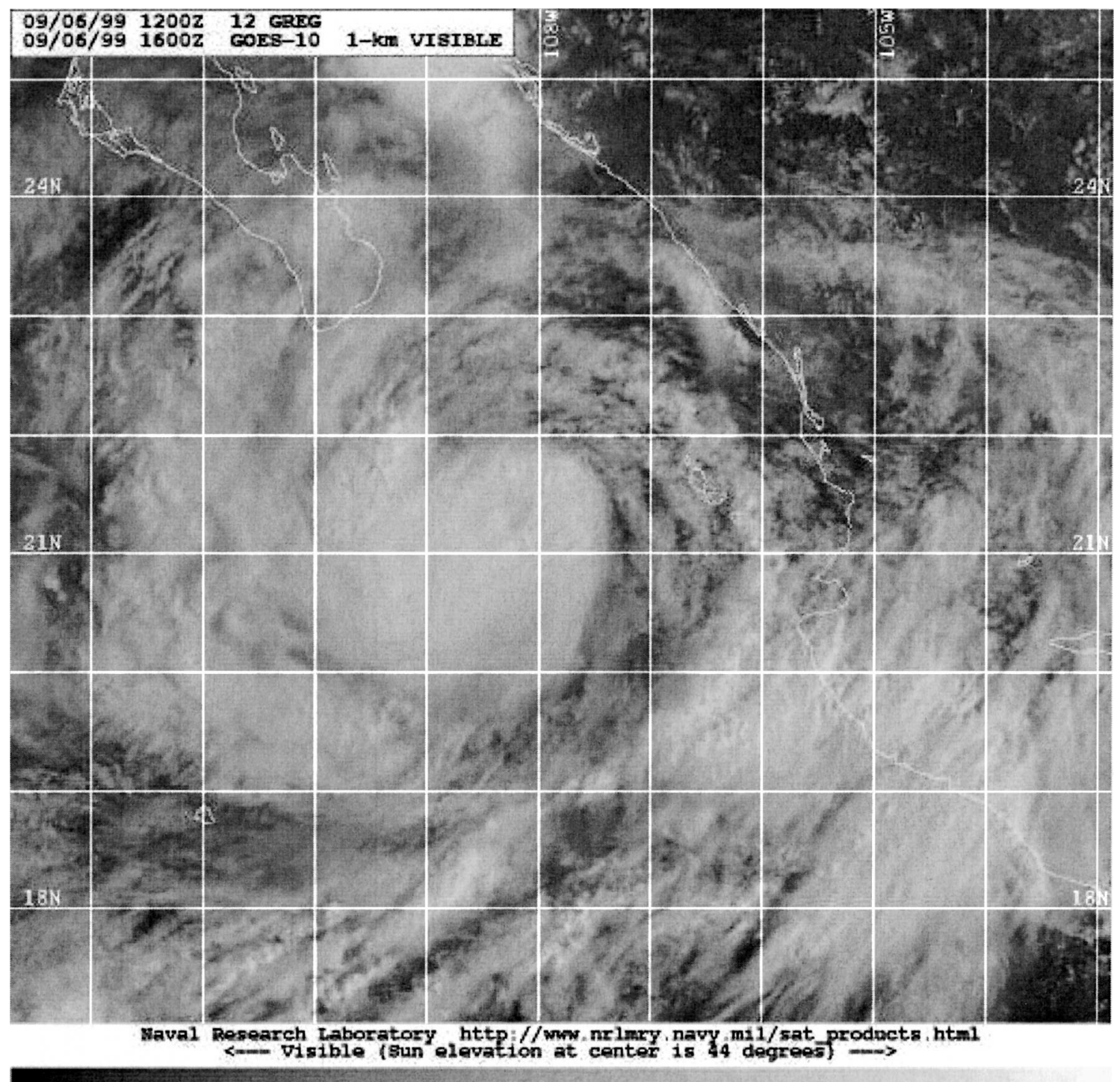

FIG. 6. GOES-10 visible image of Hurricane Greg at 1600 UTC 6 Sep 1999. Imagery provided by the Naval Research Laboratory. 
TABLE 3. A homogeneous comparison of official and SHIFOR max 1-min wind speed forecast errors (kt).

\begin{tabular}{|c|c|c|c|c|c|c|}
\hline & \multicolumn{6}{|c|}{ Forecast period $(\mathrm{h})$} \\
\hline & 0 & 12 & 24 & 36 & 48 & 72 \\
\hline 1999 Avg official error (bias) & -0.5 & 0.0 & -0.3 & -2.5 & -6.1 & -11.4 \\
\hline 1999 Avg absolute official error & 1.8 & 5.6 & 9.7 & 12.3 & 15.9 & 20.5 \\
\hline 1999 Avg SHIFOR error (bias) & -0.5 & -2.2 & -4.7 & -9.3 & -13.9 & -25.8 \\
\hline 1999 Avg absolute SHIFOR error & 1.8 & 6.7 & 11.8 & 15.8 & 20.2 & 29.3 \\
\hline No. of cases & 128 & 128 & 114 & 102 & 90 & 69 \\
\hline 1990-98 Avg official error (bias) & -0.9 & -1.3 & -2.3 & -3.9 & -5.6 & -5.9 \\
\hline 1990-98 Avg absolute official error & 3.8 & 6.7 & 10.3 & 13.1 & 14.9 & 16.6 \\
\hline 1990-98 Avg SHIFOR error (bias) & -0.9 & -3.0 & -5.7 & -8.9 & -11.4 & -15.5 \\
\hline 1990-98 Avg absolute SHIFOR error & 3.8 & 7.4 & 11.4 & 14.5 & 16.5 & 18.4 \\
\hline No. of cases & 2369 & 2364 & 2126 & 1892 & 1665 & 1283 \\
\hline
\end{tabular}

over cooler waters and further weakened. It became a depression on 8 September and dissipated the next day about $150 \mathrm{n}$ mi west-northwest of Cabo San Lucas.

During Greg's passage close to the Mexican coast, San Jose del Cabo, on the southern tip of Baja California, reported sustained winds of $35 \mathrm{kt}$ with gusts to $40 \mathrm{kt}$ and a minimum pressure of $995 \mathrm{mb}$ at $2100 \mathrm{UTC}$ 7 September. The cyclone produced torrential rains over portions of southwestern Mexico. Nearly $230 \mathrm{~mm}$ were measured in Manzanillo, about $205 \mathrm{~mm}$ in Colima, and $125 \mathrm{~mm}$ in the Islas Marias.

Media reports indicate that rains from Greg caused extensive flooding over the states of Colima, Jalisco, Michoacan, Nayarit, and Sinaloa, killing nine people. No monetary damage figures are available.

\section{h. Hurricane Hilary: 17-21 September}

The development of Hilary was associated with a tropical wave that crossed the West African coast on 29 August and reached the eastern Pacific on 11-12 September. The system moved slowly near the Mexican coast for several days while producing persistent disturbed weather. A low-level circulation formed by 17 September, and the system became a tropical depression about $475 \mathrm{n}$ mi south-southeast of Cabo San Lucas near 0600 UTC that day (Fig. 1). While moving west-northwestward, it became a tropical storm the next day. Hilary turned north-northwestward on 19 September and became a hurricane, with a banding-type eye and 65-kt winds, the next day. Movement over cooler waters caused Hilary to weaken to a tropical storm later that day and to a tropical depression on 21 September. The cyclone dissipated about $130 \mathrm{n}$ mi west of central Baja California shortly thereafter.

The only observation of tropical storm conditions was from the ship Salus, which reported 37-kt winds about $120 \mathrm{n} \mathrm{mi}$ from the center at 0000 UTC 20 September.

\section{i. Tropical Storm Irwin: 8-11 October}

Irwin formed within a tropical wave that moved across Central America and eastern Mexico on 1-3 October. This system, which spawned Atlantic basin Trop- ical Depression 11 in the Bay of Campeche on 4 October (Lawrence et al. 2001), produced disturbed weather near Acapulco on 5 October. Strong easterly vertical wind shear slowed development until 8 October, when the system became a tropical depression about $125 \mathrm{n} \mathrm{mi}$ south-southwest of Manzanillo (Fig. 1). The cyclone moved slowly north-northwestward and reached tropical storm strength later that day. Irwin was within $75 \mathrm{n} \mathrm{mi}$ of the coast of Mexico on 9 October when a strengthening midtropospheric ridge forced it to turn west-northwestward. The storm reached an estimated peak intensity of $50 \mathrm{kt}$ after this turn. A combination of northeasterly vertical wind shear and entrainment of stable air caused Irwin to weaken on 10 October. It weakened to a depression while passing near Socorro Island, and it dissipated the next day about $350 \mathrm{n} \mathrm{mi}$ southwest of Cabo San Lucas.

The only known observation of tropical storm force winds was from the ship Lincoln Spirit, which reported 45-kt winds at 1800 UTC 9 October. There were no reports of damage or casualties.

\section{Tropical depressions}

Five other tropical depressions occurred during the 1999 season, with three in July and two in August. Tropical Depression 3-E occurred from 14-15 July. Tropical Depression 4-E existed from 23-25 July and was close to tropical storm strength on 24 July. Tropical Depression 6-E developed on 26 July about $360 \mathrm{n} \mathrm{mi}$ southwest of Tropical Storm Calvin and dissipated 2 days later. Tropical Depression 9-E was observed from 13-15 August. Finally, Tropical Depression 11-E formed on 23 August from a broad low pressure system that likely resulted from a combination of a tropical wave and a background monsoon environment. Winds were near tropical storm force at genesis. However, no further development occurred, and the system dissipated the next day.

\section{Forecast verification}

The Tropical Prediction Center (TPC) issues advisories every $6 \mathrm{~h}$ on all tropical cyclones in the Atlantic 
and eastern North Pacific hurricane basins. These advisories include 12-, 24-, 36-, 48-, and 72-h forecasts of track and intensity. A "best track" position and intensity (maximum 1-min wind speed) are determined at 6-h intervals for each tropical cyclone after the fact using all available data. These best tracks (shown in Fig. 1) are the basis for verifying forecasts.

The track forecast error is defined as the great circle distance between a forecast position and a best-track position for the same time. Two intensity forecast errors are calculated-the absolute error, defined as the absolute value of the difference between the forecast and best-track wind speed, and the forecast bias, which is the algebraic difference between a forecast and a besttrack wind speed.

The skill of TPC forecasts is measured against the baseline of climatology and persistence forecasts. For track forecasts, the baseline is the forecast from the climatology-persistence (CLIPER) statistical track model (Neumann 1972). For intensity forecasts, the baseline is the forecast from the Statistical Hurricane Intensity Forecast (SHIFOR) system (Jarvinen and Neumann 1979).

Table 2 shows the average official TPC track forecast errors for 1999 in the eastern North Pacific, along with the 1999 CLIPER average errors, the NHC average forecast error for the previous $10 \mathrm{yr}$, and the average CLIPER errors for the previous $10 \mathrm{yr}$. The 1999 official track forecast errors were $15 \%-25 \%$ smaller than the average of the previous $10 \mathrm{yr}$ for all forecast periods. The 1999 CLIPER forecast errors were only about $10 \%$ better than the previous $10-y r$ average, indicating that much of the improvement in the official forecasts was due to increased forecaster skill.

Table 3 shows the average bias and average absolute errors for TPC intensity forecasts. The 1999 average bias is near or below the 1990-98 average, except at $72 \mathrm{~h}$ where it is about twice the long-term average. The 1999 absolute errors are also near or below the 199098 averages, except again at $72 \mathrm{~h}$ where it is about $25 \%$ greater. The SHIFOR forecast errors were near the longterm averages at 12 and $24 \mathrm{~h}$. They were 5\%-10\% greater than the average at $36 \mathrm{~h}, 20 \%$ greater at $48 \mathrm{~h}$, and $60 \%-70 \%$ greater at $72 \mathrm{~h}$. The official intensity forecast thus were skillful even at $72 \mathrm{~h}$.

Acknowledgments. Lixion Avila, Miles Lawrence, and Richard Pasch contributed to the writing of this report, while Stephen Baig produced the track chart. Rick Knabb produced the monthly wind shear anomalies. Satellite imagery shown in this report was provided by the Cooperative Institute for Meteorological Satellite Studies at the University of Wisconsin-Madison and the Naval Research Laboratory.

\section{REFERENCES}

Avila, L. A., and J. L. Guiney, 2000: Eastern North Pacific hurricane season of 1998. Mon. Wea. Rev., 128, 2990-3000.

Dvorak, V. F., 1984: Tropical cyclone intensity analysis using satellite data. NOAA Tech. Rep. NESDIS 11, 47 pp.

Gunther, E. B., 1978: Eastern North Pacific tropical cyclones of 1977. Mon. Wea. Rev., 106, 546-558.

Jarvinen, B. R., and C. J. Neumann, 1979: Statistical forecasts of tropical cyclone intensity. NOAA Tech. Memo. NWS NHC-10, $22 \mathrm{pp}$.

Lander, M. A., and C. P. Guard, 1998: A look at global tropical cyclone activity during 1995: Contrasting high Atlantic activity with low activity in other basins. Mon. Wea. Rev., 126, 11631173.

Lawrence, M. B., L. A. Avila, J. L. Beven, J. L. Franklin, J. L. Guiney, and R. J. Pasch, 2001: Atlantic hurricane season of 1999. Mon. Wea. Rev., 129, 3057-3084.

Mayfield, M., and E. N. Rappaport, 1998: Eastern North Pacific hurricane season of 1996. Mon. Wea. Rev., 126, 3068-3076.

Neumann, C. J., 1972: An alternate to the HURRAN tropical cyclone forecast system. NOAA Tech. Memo. NWS SR-62, $22 \mathrm{pp}$.

Pasch, R. J., and M. Mayfield, 1996: Eastern North Pacific hurricane season of 1994. Mon. Wea. Rev., 124, 1579-1590.

Simpson, R. H., 1974: The hurricane disaster potential scale. Weatherwise, 27, 169-186.

— , N. Frank, D. Shideler, and H. M. Johnson, 1969: Atlantic tropical disturbances of 1968. Mon. Wea. Rev., 97, 251-259.

Tsai, W.-Y., M. Spender, C. Wu, C. Winn, and K. Kellogg, 2000: Sea Winds of QuickSCAT: Sensor description and mission overview. Proc. Geoscience and Remote Sensing Symp. 2000, Vol. 3, Honolulu, HI, IEEE, 1021-1023. 